Article

\title{
Environmental Comfort as a Sustainable Strategy for Housing Integration: The AURA 1.0 Prototype for Social Housing
}

\author{
Álvaro López-Escamilla ${ }^{1} \mathbb{C}$, Rafael Herrera-Limones ${ }^{1, * \mathbb{C}}$, Ángel Luis León-Rodríguez ${ }^{1} \mathbb{C}$ \\ and Miguel Torres-García ${ }^{2}$ (D) \\ 1 Instituto Universitario de Arquitectura y Ciencias de la Construcción, Escuela Técnica Superior de Arquitectura, \\ Universidad de Sevilla, Av. Reina Mercedes 2, 41012 Seville, Spain; alvlopesc@alum.us.es (Á.L.-E.); \\ leonr@us.es (Á.L.L.-R.) \\ 2 Departamento de Ingeniería Energética. E.T.S. de Ingeniería, Universidad de Sevilla, \\ Camino de los Descubrimientos, s/n, 41092 Seville, Spain; migueltorres@us.es \\ * Correspondence: herrera@us.es; Tel.: +34-954-55-98-93
}

Received: 21 September 2020; Accepted: 29 October 2020; Published: 31 October 2020

\begin{abstract}
The AURA 1.0 prototype is a sustainable social housing proposal, designed by the University of Seville and built for the first Latin American edition of the prestigious Solar Decathlon competition. Different conditioning strategies were integrated into this prototype, optimized for a tropical climate, and focused on contributing positively to the health of the most humble people in society. In this moment, in which a large part of the world population is confined to their homes due to the Covid-19 pandemic, we have the opportunity (and the obligation) to reconsider the relationship between architecture and medicine or in other words, between the daily human habitat and health. For this reason, this analysis of aspects derived from the interior conditioning of the homes is carried out. The main objective of the Aura proposal is to be able to extract data through a housing monitoring system, which allows us to transfer some design strategies to the society to which is a case study, in order to promote environmental comfort and, therefore, people's health. The AURA 1.0 prototype develops flexible and adaptable living spaces, with a high environmental quality, in order to maintain the variables of temperature, relative humidity and natural lighting within a range of comfort required by the rules of the event. To achieve this end, the prototype develops an architectural proposal that combines passive and active conditioning strategies, using construction qualities and typical costs of social housing. These strategies allowed the project to achieve the first prize in the Comfort Conditions test. So, this paper presents an appropriate and tested solution that can satisfy comfortability and health of residents who live in social housing while maintaining low energy consumption.
\end{abstract}

Keywords: architecture; sustainability; solar decathlon; comfort; health; environment; prototype; indoor conditioning; daylight factor; monitoring; building

\section{Introduction}

The Solar Decathlon Competition is the most prestigious international university competition on sustainable habitat, originally sponsored by the U.S. Department of Energy. Universities from all over the world participate in it, in collaboration with institutions and private companies, with the aim of designing, building, and monitoring a prototype of a housing cell with the highest level of self-sufficiency and use of renewable energies. This prototype will fulfill its double function: on the one hand, it will be a pavilion that can be visited, and on the other, a cell that can be monitored and technically measured [1]. 
However, this is not the only purpose of the competition. Throughout the entire process, students (undergraduate, master or PhD), tutored by teachers and researchers [2-5], develop ten tests-hence the name decathlon-apparently as diverse as: Sustainability, Innovation, Communication, Housing Operation, Social Relevance, Architecture, Engineering and Construction, Energy Balance, Comfort Conditions, Energy Efficiency [6,7].

The main stage of the competition takes place in the two weeks that make up the final phase, when different prototypes are evaluated in the "Solar City", the venue proposed by the Organization. However, what is really relevant is the learning process through the resolution of a project (urban and social) from which, finally, the aforementioned archetype of sustainable habitat is extracted, in order to be tested with scientific and humanistic parameters.

The version of the competition, Solar Decathlon Latin America and Caribbean 2015 (Cali, Colombia), to which the prototype presented in this article was submitted, unlike previous editions [8-13], was given a social approach, which allowed researching on other architectural typologies and sustainable-healthy construction solutions, where the transfer to society of the environmental strategies implemented in these prototypes gained special relevance. The objective was no longer to present a housing cell where excellent comfort conditions and minimum energy consumption were achieved on the basis of technology decontextualized socioeconomically from the society where the competition was held [14]. The time had come to design a prototype of low-energy consumption housing for vulnerable society sectors, focused, therefore, on working under the concept of energy poverty [15], which is in many cases responsible for not allowing to achieve minimum conditions of comfort and healthiness of domestic space [16].

Although comfort conditions in the human environment (temperature, humidity, lighting, air quality, etc.) do not always have a direct impact on the health of the user [17], it is usually understood that optimum comfort conditions in buildings do have direct consequences on human health [18-20].

For this reason, in this article, the monitoring strategy [21-23] used in the prototype is considered a fundamental part of the project and aimed at collecting data on the indicators that, traditionally, scientifically constitutes the comfort parameters [24,25]: temperature, humidity, and lighting [26]. Because these data are considered indicative needed to assess the environmental quality of the prototype [27-29] and to indicate where to direct efforts in future versions it improved in subsequent investigations [30,31].

Therefore, considering a space-temporal context, this article belongs to the Solar Decathlon edition that was held in Santiago de Cali (Colombia) in December 2015, in which many Latin American and European universities participated, in addition to the local ones (Table 1).

The Solar City is open to the teams 10 days before the start of the competition, so the prototypes have to be assembled during this period, and is undoubtedly one of the challenges of the competition [32]. Each team will have to design the construction process of its prototype, so that it can be assembled in the estimated time, we are talking about prefabricated architecture (Figure 1).

Table 1. Teams participating in first Solar Decathlon in Latin America.

\begin{tabular}{ccc}
\hline Project & University & Country \\
\hline La CasaUruguaya & ORT University & Uruguay \\
Casa ALERO & Pontifical Javerian University of Cali and ICESI University & Colombia \\
AURA & University of Seville and University of Santiago de Cali & Spain + Colombia \\
unSOLAR & National University of Colombia - Medellin Campus & Colombia \\
SMART & Technology University of Panama and Western New England University & Panama + USA \\
KUXTAL & Monterrey Institute of Technology and Higher Studies, Queretaro Campus & Mexico \\
MIHOUSE & San Buenaventura University and Autonomous Occident University & Colombia \\
AYNI & National University of Engineering of Peru & Peru \\
HABITEC & La Salle University and University of Applied Sciences East Westphalia-Lippe & Colombia-Germany \\
+HUERTO +CASA & University of the Andes & Colombia \\
VRISSA & Seine Valley of the Cauca & Colombia \\
PEI & Pontifical Javerian University of Bogotá & Colombia \\
YARUMO & Pontifical Bolivarian University - Medellín & Colombia \\
SOL_ID & London Metropolitan University & UK \\
\hline
\end{tabular}




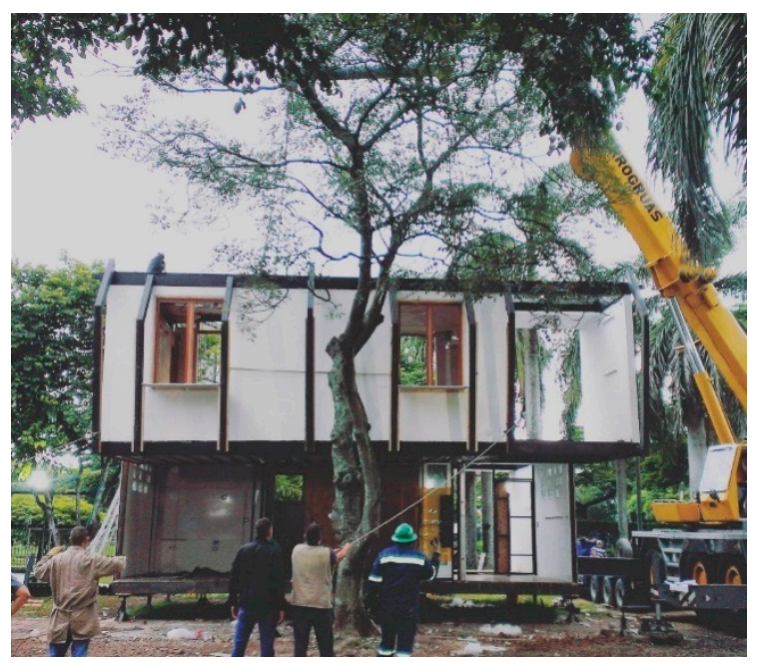

Figure 1. Image of the prototype assembly process.

In this edition, the first one held in Latin America, the objective was to propose a social housing model that would be the result of a previous urban project with a high building density. As indicated above, all the prototypes submitted to the competition and built at a 1:1 scale in the Solar City were evaluated based on 10 tests (Table 2). As it can be seen, some were evaluated by a jury of experts in the field and others, from data obtained from monitoring environmental and energy conditions: temperature, background noise level, illuminance, electricity, water consumption, etc.

The team led by the University of Seville, which presented the AURA 1.0 prototype, was the winner of the "Comfort Conditions" test [33]. The main purpose of this article is, therefore, to explain what conditioning strategies were implemented in this prototype, attempting to overcome the atmospheric conditions typical of the tropical climate that prevails in Santiago de Cali in December, in order to achieve optimum interior comfort conditions, taking into account the parameters that influence the health of the inhabitant of the dwelling. The research focuses specifically on the Latin American context, in which the special geo-social conditions cause the criteria of passive solar architecture and use of "natural" resources to be more important, due to the high rates of energy poverty present in most of these countries. To achieve this end, the prototype develops an architectural proposal that combines passive and active conditioning strategies, using construction qualities and typical costs of social housing.

Table 2. Analysis of the 10 contests of the Competition: summary table generated from the SDLAC15 Competition Rules, but with our own re-drafting.

\begin{tabular}{|c|c|c|}
\hline CONTEST & DESCRIPTION & JUDGING \\
\hline Comfort conditions & $\begin{array}{l}\text { Measures interior conditions such as temperature, humidity, acoustics, } \\
\text { lighting and air quality to assess the sensation of interior comfort in each } \\
\text { housing solution. }\end{array}$ & Monitorig \\
\hline Architecture & $\begin{array}{l}\text { bioclimatic strategies for the future of social housing in the context of Latin } \\
\text { America and the Caribbean. }\end{array}$ & Judges \\
\hline Engineering and construction & $\begin{array}{c}\text { Evaluates feasibility and adequate integration of the structural, electrical, } \\
\text { plumbing and solar design and that of the enclosure for low-cost social } \\
\text { housing. }\end{array}$ & Judges \\
\hline Energy efficiency & $\begin{array}{c}\text { Evaluates suitable design of the dwelling's systems to achieve a reduction in } \\
\text { energy consumption. }\end{array}$ & Monitorig \\
\hline Electrical balance & $\begin{array}{c}\text { Measures the level of electrical self-sufficiency of the dwelling through } \\
\text { balancing electricity generation and consumption. }\end{array}$ & Monitorig \\
\hline Sustainability & $\begin{array}{l}\text { Focused on reducing environmental impact in the long term. Evaluates } \\
\text { strategies to properly manage the topics of architecture, engineering and } \\
\text { construction, energy efficiency, urban design, and economic viability. }\end{array}$ & Judges \\
\hline
\end{tabular}


Table 2. Cont

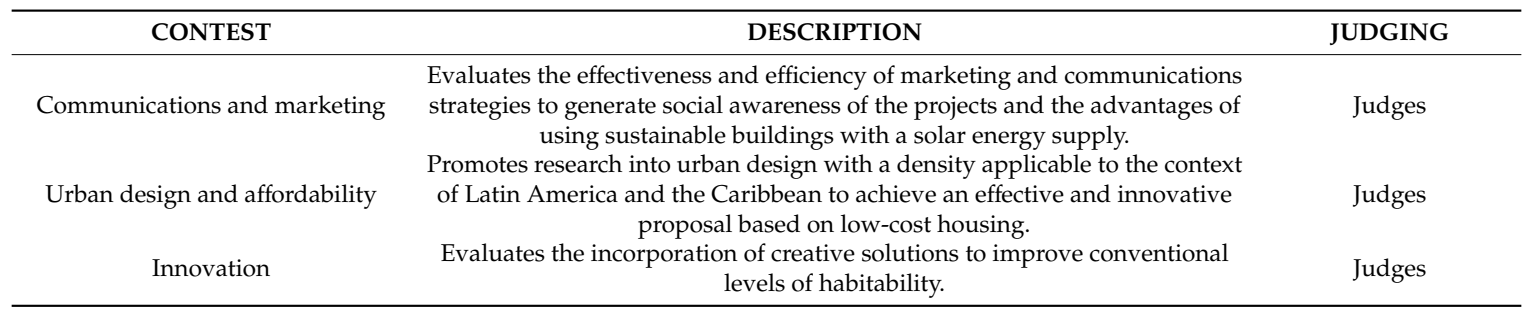

\section{Starting Conditions}

In order to understand the conditioning strategies implemented in the AURA 1.0 prototype, first of all, it is necessary to analyze what the comfort conditions are and under what ranges the competition scored the test [34], so that we can understand at what times of the day and under what strategies the prototype was scoring well and when it was not.

However, on the other hand, it is necessary to analyze under which atmospheric conditions the competition was being held, in order to put into context which were the external hygrothermal variables that had to be overcome in order to keep the internal hygrothermal conditions in the optimal scoring ranges (Figure 2).

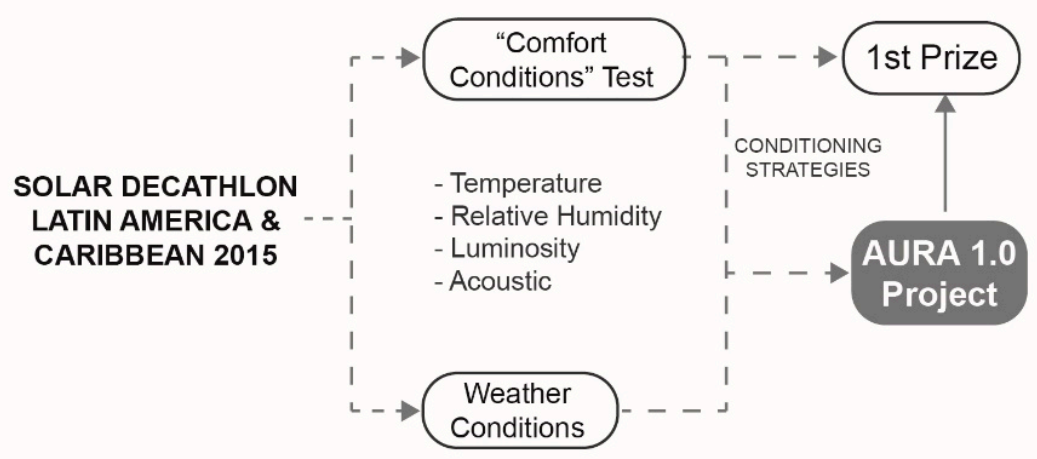

Figure 2. Diagram of the used methodology.

\subsection{Comfort Condition Test in SD2015}

The comfort conditions test, a case study in this article, had a maximum score of 100 points, which were divided into 4 categories (Table 3):

Table 3. Score of the "Comfort Conditions" test, taken from the competition rules.

\begin{tabular}{|c|c|c|c|c|}
\hline Test & Score & Sub-Categories & Score & Description \\
\hline \multirow{4}{*}{$\begin{array}{l}\text { Comfort } \\
\text { Conditions }\end{array}$} & \multirow{4}{*}{100} & Temperature & 50 & \multirow{4}{*}{$\begin{array}{l}\text { The interior temperature of the house was collected } \\
\text { continuously through } 2 \text { sensors. } \\
\text { During the days of competition, the relative humidity of the } \\
\text { different points of the prototype was recorded with } 3 \text { sensors } \\
\text { This parameter could be known through } 1 \text { lighting sensor } \\
\text { strategically placed by the competition organization } \\
\text { The organization carried out an acoustic test in isolation and a } \\
\text { night, with the venue closed to the public. }\end{array}$} \\
\hline & & $\begin{array}{l}\text { Relative } \\
\text { Humidity }\end{array}$ & 20 & \\
\hline & & $\begin{array}{l}\text { Natural } \\
\text { lighting }\end{array}$ & 20 & \\
\hline & & Acoustics & 10 & \\
\hline
\end{tabular}

Temperature: To obtain the maximum score, the interior temperature of the prototype must be kept within a range of $24{ }^{\circ} \mathrm{C}$ and $28{ }^{\circ} \mathrm{C}$. However, reduced points can be obtained up to a tolerance of $2{ }^{\circ} \mathrm{C}$ above and below the established range (Table 4 ). These reduced points were given on a proportional and linear basis between the highest and lowest scoring value. 
Table 4. Sub-category score range.

\begin{tabular}{ccc}
\hline & Full Points & $\mathbf{T}_{\min } \leq$ Temperature $\leq \mathbf{T}_{\max }$ \\
\cline { 2 - 3 } Temperature & Reduced Points & $\mathbf{T}_{\min }-2 \leq$ Temperature $\leq \mathbf{T}_{\max }$ \\
\cline { 2 - 3 } $\mathbf{T}_{\min }=2{ }^{\circ} \mathbf{C}$ & $\mathbf{T}_{\min } \leq$ Temperature $\leq \mathbf{T}_{\max }+2$ \\
\cline { 2 - 3 } $\mathbf{T}_{\max }=28{ }^{\circ} \mathbf{C}$ & No Points & $\mathbf{T}_{\max }+2 \leq$ Temperature $\leq \mathbf{T}_{\min }-\mathbf{2}$ \\
\cline { 2 - 3 } & Full Points & Relative humidity $\leq 60 \%$ \\
Relative Humidity & Reduced points & $60 \%<$ Relative humidity $<70 \%$ \\
& No points & Relative humidity $\geq 70 \%$ \\
Natural lighting & Full Points & $4 \%<$ Daylight Factor \\
& Reduced points & $2.5 \%<$ Daylight Factor $<4 \%$ \\
& No points & Daylight Factor $<2.5 \%$ \\
\hline
\end{tabular}

Relative humidity: To obtain the maximum score, the relative humidity of the prototype must always be kept below $60 \%$. However, reduced points can be obtained if this humidity is between $60 \%$ and $70 \%$.

Natural lighting: To measure this parameter, a light sensor is placed in the living room, which must be at a height of $0.90 \mathrm{~m}$ and at least $2 \mathrm{~m}$ away from any window. All the points are obtained if the Daylight Factor is higher than 4\%, and a reduced score is obtained if the Daylight Factor is between $4 \%$ and $2.5 \%$. Below $2.5 \%$ no score is obtained. The reduced points, in the same way, were given in a proportional and linear way between the highest and lowest scoring value.

Acoustic behavior: This subcategory is scored on the basic of two parameters, the acoustic insulation to the outside and the reverberation time in the living room (Table 5). However, this sub-category would be illogical in the face of very open-to-the-outside architectures submitted to this edition of the competition, which were adjusted to tropical climate conditions.

Table 5. Score for the subcategory "Acoustic behavior".

\begin{tabular}{ccc}
\hline \multirow{2}{*}{ Acoustic Value } & Full Points & Acoustic value $\geq 42 \mathrm{~dB}$ \\
\cline { 2 - 3 } & Reduced Points & $30 \mathrm{~dB}<$ Acoustic value $<42 \mathrm{~dB}$ \\
\cline { 2 - 3 } Reverberation Time & No Points & Acoustic value $<30 \mathrm{~dB}$ \\
\hline \multirow{2}{*}{ Full Points } & Reverberation time $\leq 0.8 \mathrm{~s}$ \\
& Reduced Points & $0.8 \mathrm{~s}<$ Reverberation time $<1.2 \mathrm{~s}$ \\
Ne Points & Reverberation time $>1.2 \mathrm{~s}$ \\
\hline
\end{tabular}

\subsection{Climatic Conditions of the Competition Location: Santiago de Cali (Colombia)}

The entire territory of Colombia has a tropical climate modified by altitude. This means that there are no great differences between the different seasons, the summers or winters are differentiated by the amount of received solar radiation.

The city of Santiago de Cali is located in southwestern Colombia, in the valley between the western and central branches of the Colombian Andes, an area known as Valle del Cauca. The coordinates of Cali are latitude $3^{\circ} 27^{\prime \prime} \mathrm{N}$ and longitude $76^{\circ} 32^{\prime \prime} \mathrm{W}$ and it is $995 \mathrm{~m}$ above sea level (Figure 3).

In the humid tropical climate (also known as savanna climate according to the Koppen Climate Classification), the weather factors change suddenly. In comparison to temperate climates, the influence of direct radiation decreases while diffuse radiation increases. Rainfall is a very important element to take into account, as well as relative humidity, which is considered very high. Consequently, buildings need to be prepared to deal with diffuse light, as well as effective covers against rain and abundant solar radiation (Figure 4). 


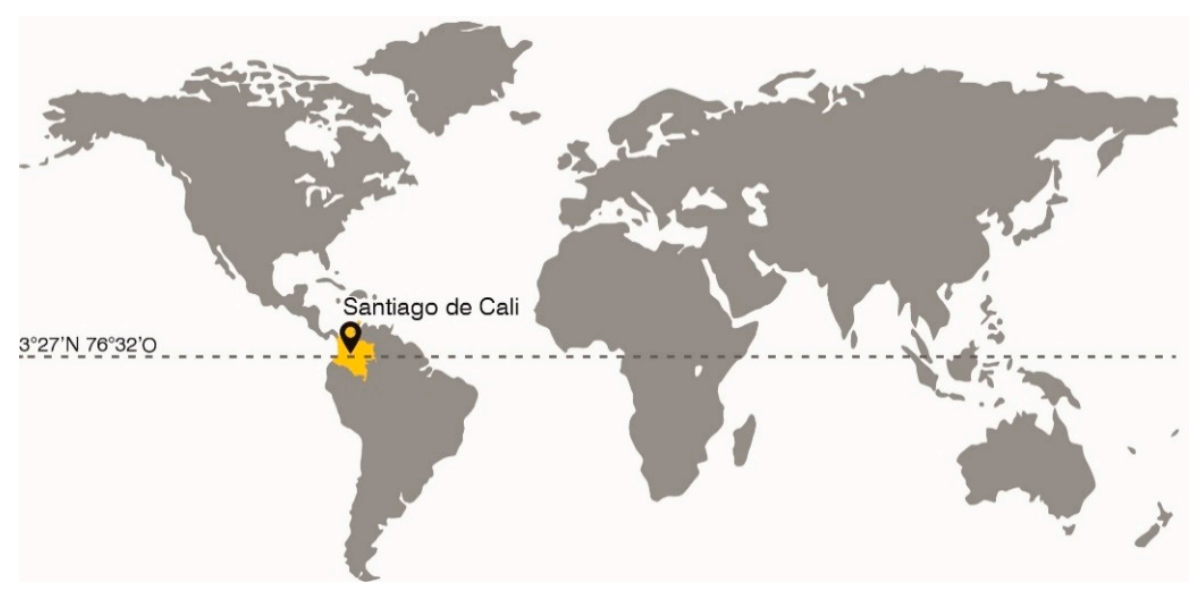

Figure 3. Location map of Santiago de Cali.

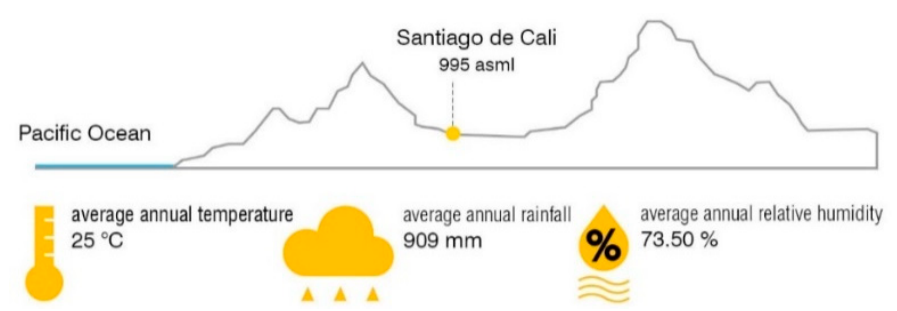

Figure 4. Average climatic values of Santiago de Cali.

In this article, special importance is given to the atmospheric conditions which occurred during the competition period, 4-15 December (Figures 5 and 6), and had to be counteracted in order to achieve the comfort ranges imposed by the event's organization. On the other hand, it is worth noting the absence of rainfall during these days. Dates are obtained by the network of measurement sensors that staff of the Solar Decathlon installed in outdoor spaces where the event was held.

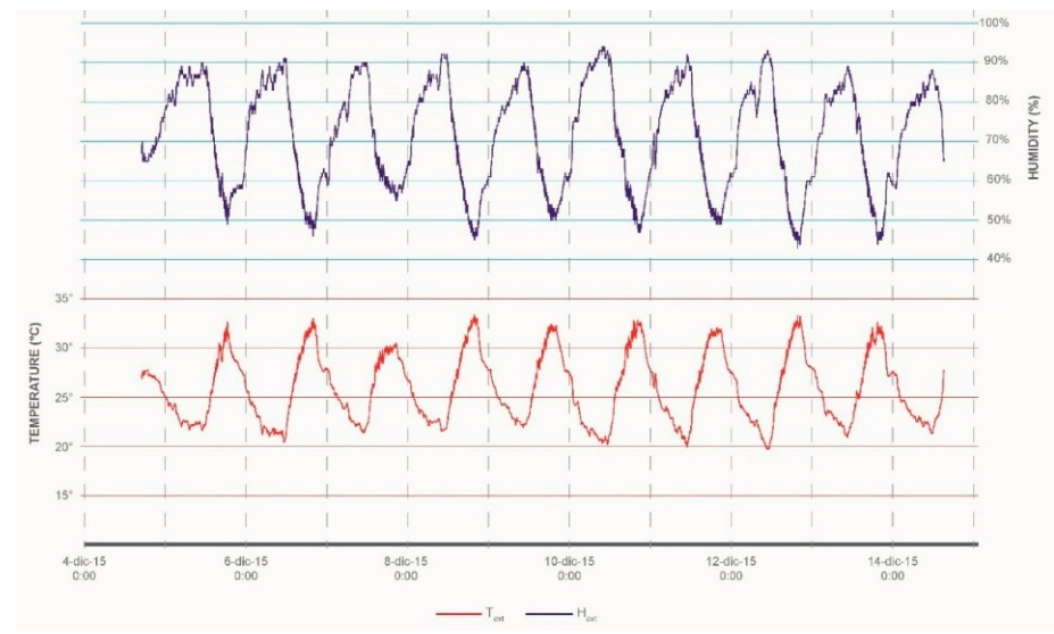

Figure 5. Hygrothermal data in Santiago de Cali, 4-15 December. Source: Solar Decathlon staff. 


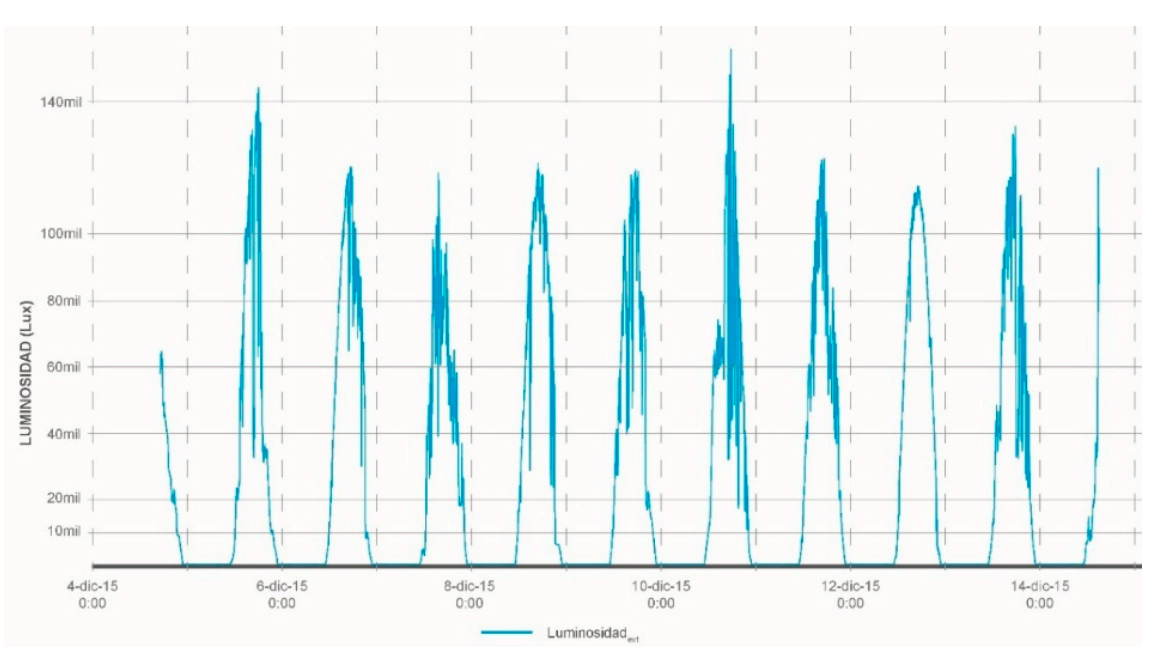

Figure 6. Lighting data in Santiago de Cali, December 4-15. Source: Solar Decathlon staff.

\section{Case Study: AURA Project}

The development of AURA Project [35] aims to unite both ends of the Latin American reality: the American and the Southern European. They are both sides of the same coin, not only in architecture but also in lifestyle; they both inhabit what could be called the "architecture of warm countries" [36].

Social housing generally has two weaknesses: Firstly, when it is built as a low-cost house, frequently the comfort conditions do not reach the minimum levels, this is due to a low quality design where there is a reduction of the spaces, or by the use of low quality materials, by the bad quality of the carpentry, little efficient isolations, etc. However, we have to add that the inhabitants of these houses are people and families in a situation of economic vulnerability, so that in most cases they cannot use air conditioning equipment to alleviate the bad conditions of comfort because they cannot face the economic outlay that this implies, we are talking about energy poverty.

Therefore, when we talk about sustainable social housing, we refer to an architecture where the maximum comfort of the inhabitants is sought with the least possible energy consumption, that is, that the house itself is placed as much as possible within the comfort range, which is what we have quantified in this publication.

When this is not possible, it is necessary to make use of air conditioning technology. Therefore, this paper argues that air conditioning equipment should be an integrated part of social housing, always focused on the energy self-supply of the home and aimed at alleviating peak atmospheric situations where passive strategies are not able to generate minimum comfort conditions.

The AURA 1.0 prototype is an appropriate and tested solution that can satisfy comfortability and health of residents who lives in social housing while maintaining low energy consumption.

\subsection{Territorial Scale and Urban Scale-Master Plan}

The Project has to be explained from the three-dimensional mesh that holds all the services that the user needs to inhabit. This three-dimensional mesh is developed from the scale of the city, reaching the scale of the prototype/housing cell.

At a territorial and urban level, a Master Plan is drawn up (Figure 7) which, starting from the territorial scale (the city itself), ends up landing in the most optimum area of urban expansion and configuring an eco-neighborhood, made up of facilities, equipment, open areas, and residential buildings designed with passive solar parameters. 


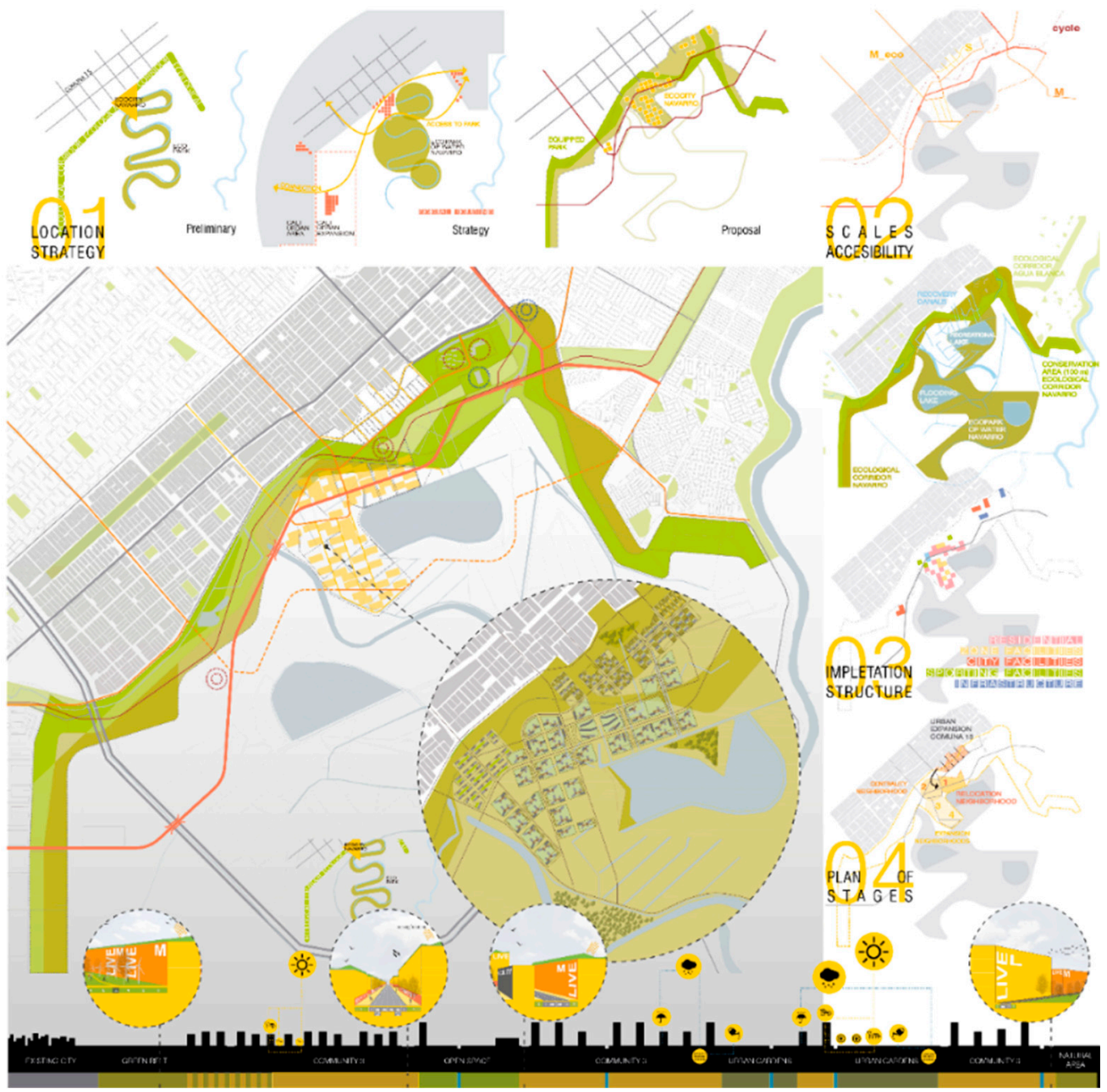

Figure 7. Master Plan.

In this way, the housing proposal ends up being materialized in social housing buildings, adapted to the climatic conditions of tropical climate.

\subsection{Building Scale}

From the research on the rehabilitation of obsolete structures existing in Spain after the real estate crisis that resulted in a large number of unfinished buildings throughout the Spanish territory, the idea of a three-dimensional mesh or network arises. To this end, from an urban approach to inhabit the city, the proposal envisages the construction of this mesh as a way of organizing the territory and its scales (from the general: Master Plan; to the particular: prototype built in the Solar City); and it accumulates all the technical, service, and basic structural aspects for the exercise of inhabiting. It goes from the territory to the housing, passing through the neighborhood and the building.

Thus, the main concept behind the building-scale project refers on its development in two phases, based on a system of progressive occupation from the mentioned main three-dimensional network (Figure 8):

- Phase 0 (initial): in this phase the community part of the building is configured. The three-dimensional structural mesh that distributes the communications and the facilities throughout building. The entire structural and functional system is configured in this phase, forming a spatial grid, in which the communications are distributed horizontally and the installations vertically. This mesh will be the container of the habitable volumes, dimensions $9 \times 9 \times 3 \mathrm{~m}$, where different homes will be installed. 
- Phase 1 (occupation): Self-construction, simple construction systems are proposed, which can be developed by the inhabitants of the building themselves, under technical bases previously defined by architects and under their supervision.

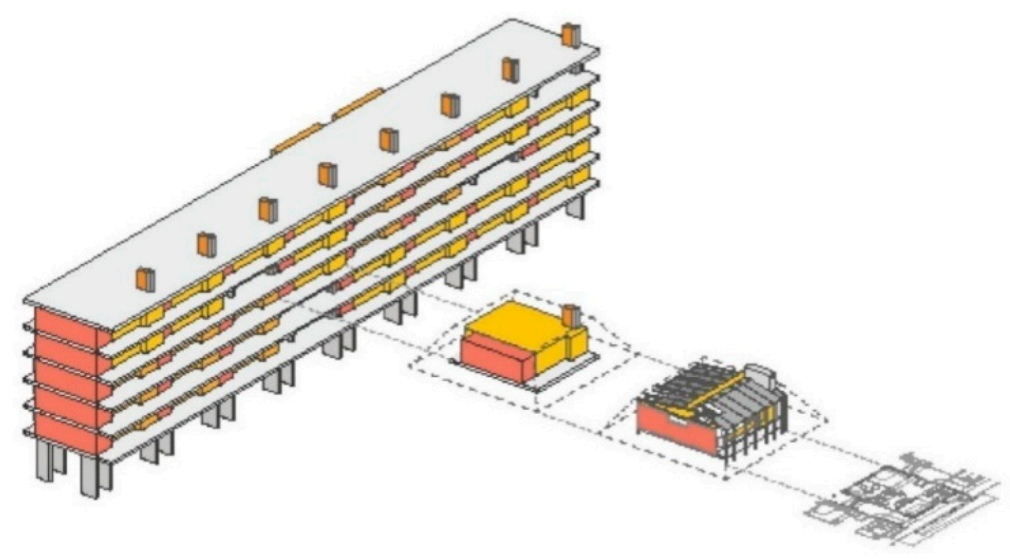

Figure 8. Decantation process from the collective building to the prototype in the Solar City.

A system of porticoes is formed by panels that act as prefabricated reinforced concrete load-bearing walls, to avoid seismic loads on the building, this being braced with plates made of the same material to form the floor the slab of the different floors. This main network is complemented by a vertical communication system, which includes facilities and communication cores, in order to obtain the highest possible level of accessibility in height.

As for the facilities, it is expected that they will be integrated into the three-dimensional mesh, so the different networks will be led to the points of attachment in the access to the house. It is a system, therefore, where all its parts are configured from industrialized elements, providing quality assurance to the technique of self-construction, so deeply rooted in the humblest strata of Santiago de Cali.

This is due to the fact that industrialization is a rational and automated production process, which involves advanced designs of production, manufacturing, and management technologies, where materials, transport, and mechanized techniques are used in series with the aim of achieving the highest possible productivity [37-40].

The industrial manufacturing process generates higher quality end products, shorter delivery times, more flexibility, safer working conditions, waste minimization, more possibilities for reuse and, consequently, greater respect for the environment [41,42].

\subsection{Housing Scale-Architectural Concept}

The housing cell was formed based on a set of architectural concepts that arise from the need to respond to a social housing solution in a Latin American context:

- Dwelling decompaction

It is understood that the concept of traditional compact housing must be fragmented, thus appearing the transition spaces between the different functional pieces (Figure 9). The relevance of these spaces becomes clear to the extent that they create new uses not foreseen in the home or that they give rise to situations that help promote the functional flexibility of the dwelling. This contributes to the following concept: perfectibility. 


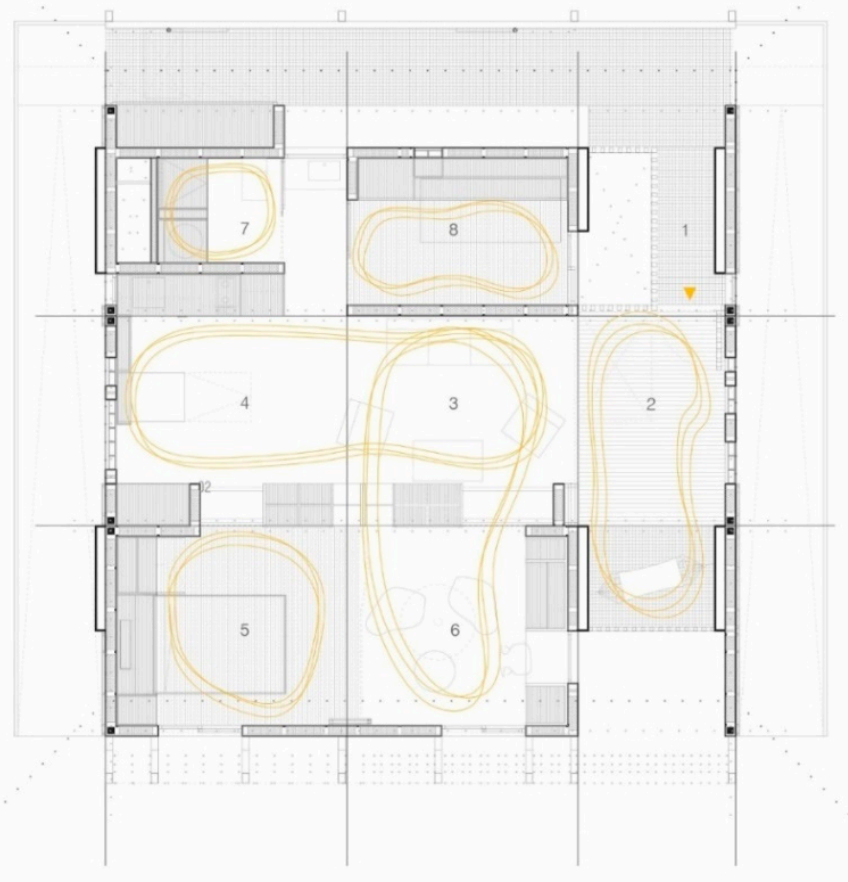

Figure 9. Scheme adaptable spaces that make housing: 1.Access, 2.Hallway, 3.Living room, 4.Kitchen, 5.Use $n^{\circ} 1,6$.Use $n^{\circ} 2,7$. Bathroom, 8.Use $n^{\circ} 3$.

- Progressivity and adaptability

By understanding, in the social context in which this project is located, the difficulty of a family to completely occupy one of the housing volumes that make up the collective building, a process of progressive occupation of this space is programmed (Figure 10).

Once the house is completed, you will have the option to improve/perfect it with the implementation of active air conditioning elements that contribute to maintain an optimal thermal comfort, or others in order to give a better answer to the problems that every family faces. Therefore, the housing is progressively improved over time and the family could increase its "social status" without being forced to move.

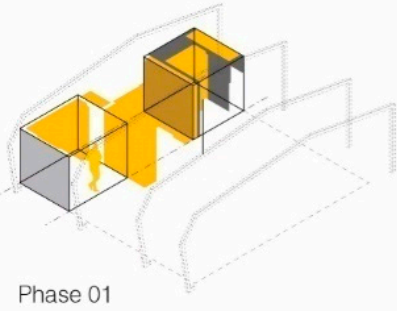

Figure 10. Diagram of housing space occupation phases.

- Equipped furniture

Following the concept of the disintegration of the house, it shapes its different interior spaces based on the layout of the furniture, which will mutate its position and shape depending on the 
different needs that arise in the house throughout the day. On the other hand, it will also have the function of providing different services to the house: conditioning installations, solar chimney, electrical installation, etc. (Figure 11).Therefore, a new level of flexibility is provided within the home according to the needs of its inhabitants.

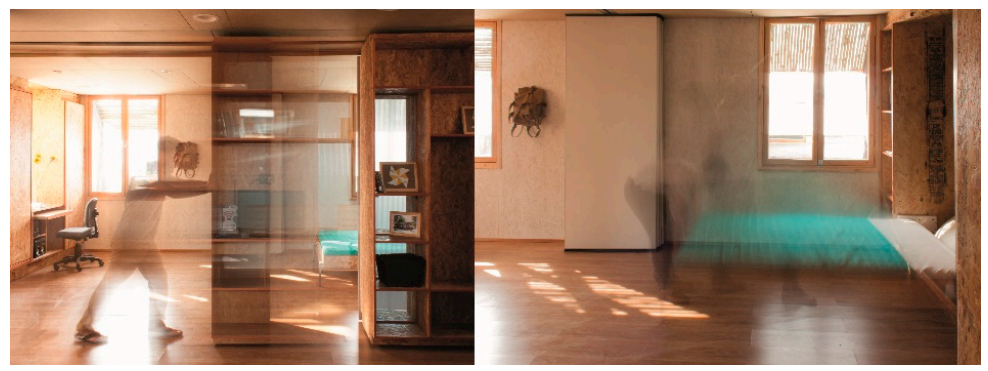

Figure 11. Interior photos of the prototype: mobile furniture and folding bed.

- Hallway

AURA 1.0 Project introduces a new element to social housing with the aim of providing additional values to the minimum housing module (Figure 12):

a. Ventilation: The "hallway" module works as a bioclimatic dumper between homes, which guarantees cross ventilation in the home, taking advantage of the benefits of the city climate, which provides a pleasant breeze every day at sunset. This air movement contributes to increase the feeling of thermal comfort in the house.

b. Lighting: It works as a transition space between the exterior and the interior of the house, obtaining a graduated light from the gallery of collective access to the interior of the house. The "hallway" module, provided with openings to the outside, allows the light to be filtered and dimmed, contributing to obtaining quality and comfortable lighting in the interior spaces for the development of the different domestic activities (Figure 13).

c. Noise: This element works as an acoustic damper between adjoining houses. Due to its configuration, this space allows each home to have four exterior facades, which improves the acoustic behavior of each one of them.

d. Health: This is the organ on which the rest of the conditioning strategies are based, contributing, on the one hand, to the physical health of the inhabitant by achieving optimum hygrothermal and lighting values; and on the other, to mental health, integrating "the street", urbanity and territory inside the home. We are facing a society very used to interacting with the environment, so that suppressing this component of the housing cell would cause a sense of bewilderment of the individual that could lead to pathology. It is an extension of the house, a kind of a covered but open space that allows the promotion of neighborhood relations, losing its border status between the public and the private, the individual and the collective.

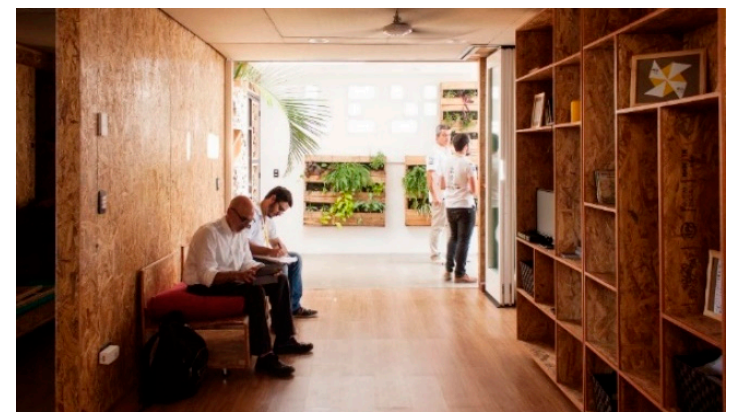

Figure 12. Photo of the hallway as seen from inside the prototype. 


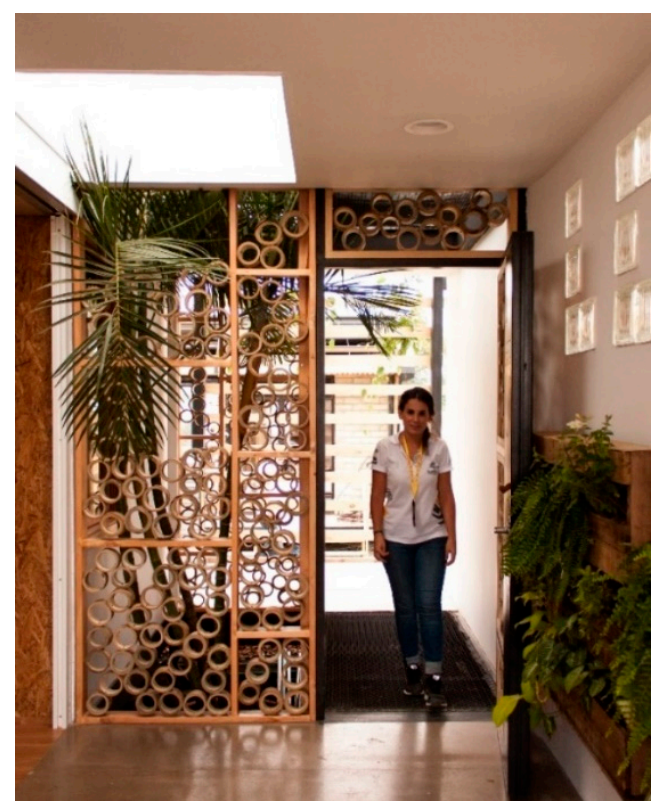

Figure 13. Photo of the entrance hall and access to the prototype.

\subsection{Housing Scale-Conditioning Strategies}

Having analyzed the climate of Santiago de Cali, characterized by high temperatures in certain times of the day, high humidity, torrential rain likelihood, and a breeze at sunset, the team responsible for carrying out the AURA 1.0 Project understood that in order to reach the comfort levels that the event organizers had set as a target, both passive and active conditioning strategies would have to be implemented [43].

It was understood that the inclusion of an air conditioning in the design, fed with the energy generated by the house through the photovoltaic solar installation on the roof of the prototype, would be necessary to counteract both the maximum temperature peaks and the high relative humidity of the place (Figure 14). In addition, two ceiling fans were installed to encourage air movement inside the house.

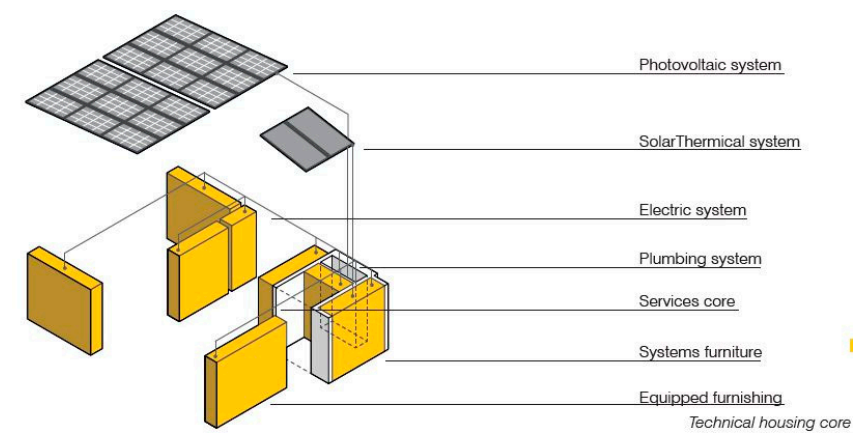

Figure 14. Scheme about generation and energy consumption.

It is therefore important to emphasize that among the minimum equipment required to provide social housing, in this case in a tropical climate, with minimum living conditions, there are the air conditioning. Most of the regulations on social housing in different countries detail minimum construction qualities or the size of the spaces. However, in order to guarantee the health of the inhabitant, it is necessary to provide the housing with active air conditioning systems wherever the climatic conditions do not allow maintaining optimum comfort conditions continuously over time. 
On the other hand, a series of passive conditioning strategies are implemented, which would contribute both to hygrothermal comfort and a reduction in energy consumption by the refrigeration equipment:

- Ventilated facade-South elevation

An outer skin was designed for the south elevation of the collective building, so that it would contribute to unifying the image of the proposal and guarantee the safety of the users-inhabitants during the self-construction phase in which not all the plots of the three-dimensional mesh (collective building) would be occupied at the same time. This would provide a certain guarantee of safety, playing the role of a skin on the building, so that the common areas can be used effectively and guaranteeing the safe self-construction of each home (Figure 15).

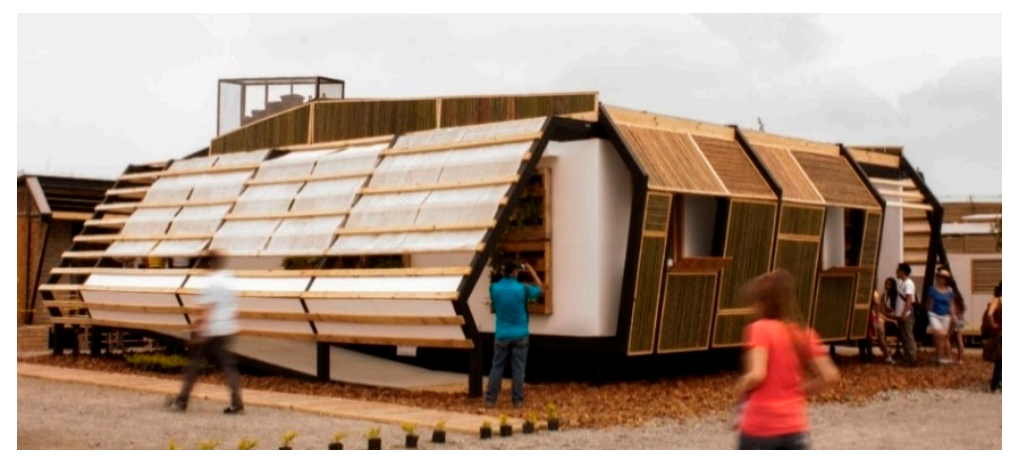

Figure 15. Photo of the south-east facade.

This outer skin is light and permeable, designed with wild cane framed (Arundodonax) in a wooden perimeter, it works as a filter absorbing direct sunlight, but allowing air to pass through, besides being an answer to the important problem of dust in the city breeze. The orientation of the wild cane is horizontal and the exterior carpentry elements are integrated into the established modulation.

This envelope is supported by a modulated and visible metal structure of metal profiles, which form both the ventilated facade and the roof of the building. These profiles of the envelope generate an asymmetric sloping roof, which provides the necessary slope to drain the water in episodes of heavy rain (Figure 16).

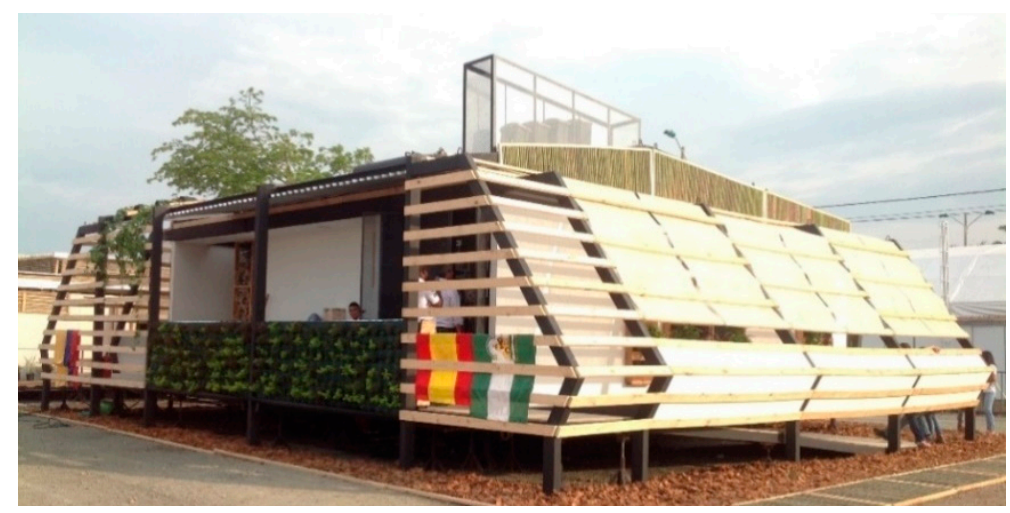

Figure 16. Photo of the north-east facade.

- Enclosures with low thermal inertia

Given the climate of Santiago de Cali, the absence of thermal inertia in the enclosure panels was chosen, since it was understood that this would be counterproductive in maintaining optimal thermal conditions inside the prototype (Figure 17). 


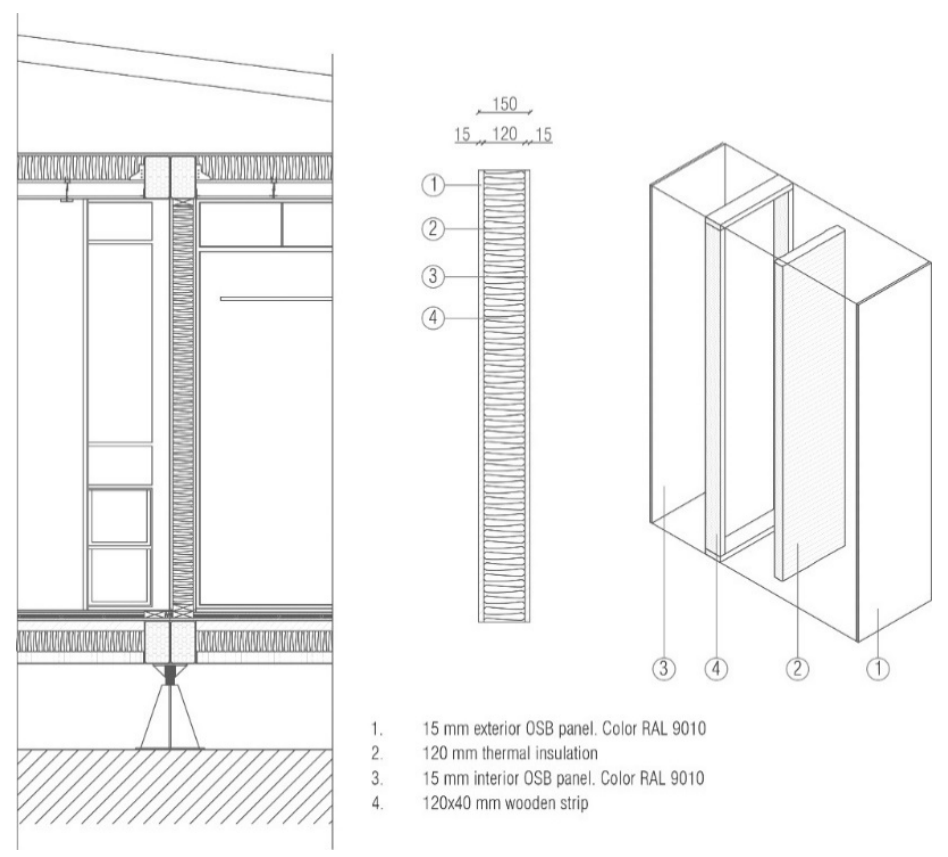

Figure 17. Exterior facade without thermal inertia.

- Solar chimney

Taking advantage of the solar radiation of the place where the event was held, a solar chimney was installed, which helped to evacuate the warmer air from inside the house, thus favoring both air movement and air renewal.

\section{- Sunlight Reflector}

Using a solar reflector, included in the structure of the ventilated facade, the sunlight is directed towards the interior of the house, bouncing it off the roof and thus achieving optimum diffused lighting. The warm colors used in the ceiling and interior walls also contribute to this (Figure 18).

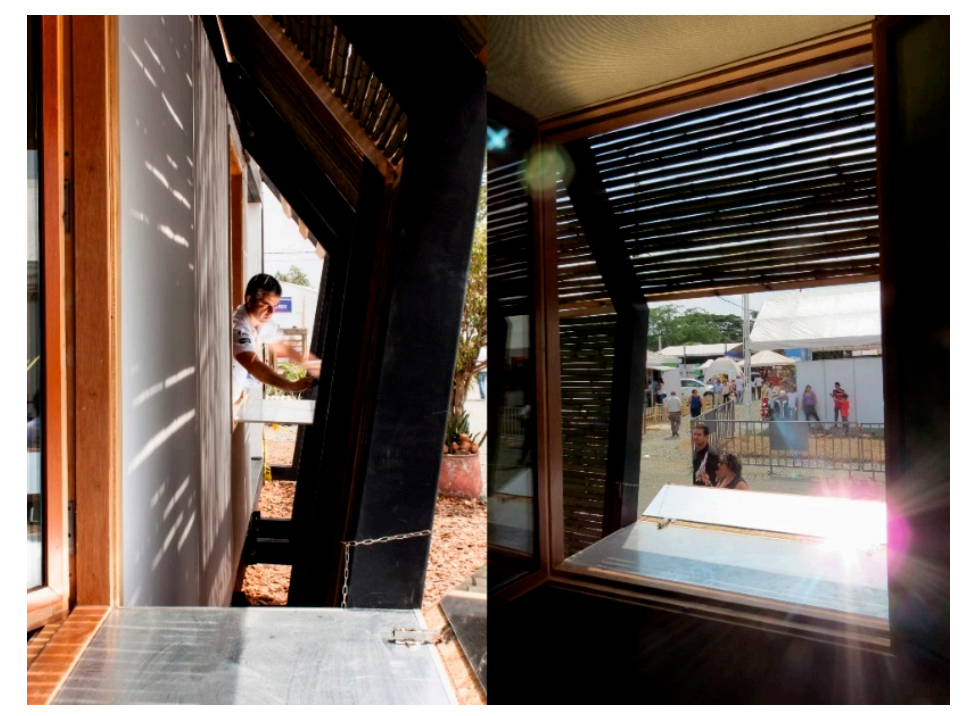

Figure 18. Image of one of the solar reflectors. 


\section{Environmental Behavior of the Prototype}

Although the AURA 1.0 Project won 3rd prize in the overall classification (adding up 10 tests) of the competition, in the specific "Comfort Conditions" test it managed to be the prototype that obtained the best results, thanks to the combination of active and passive conditioning strategies (Figure 19).

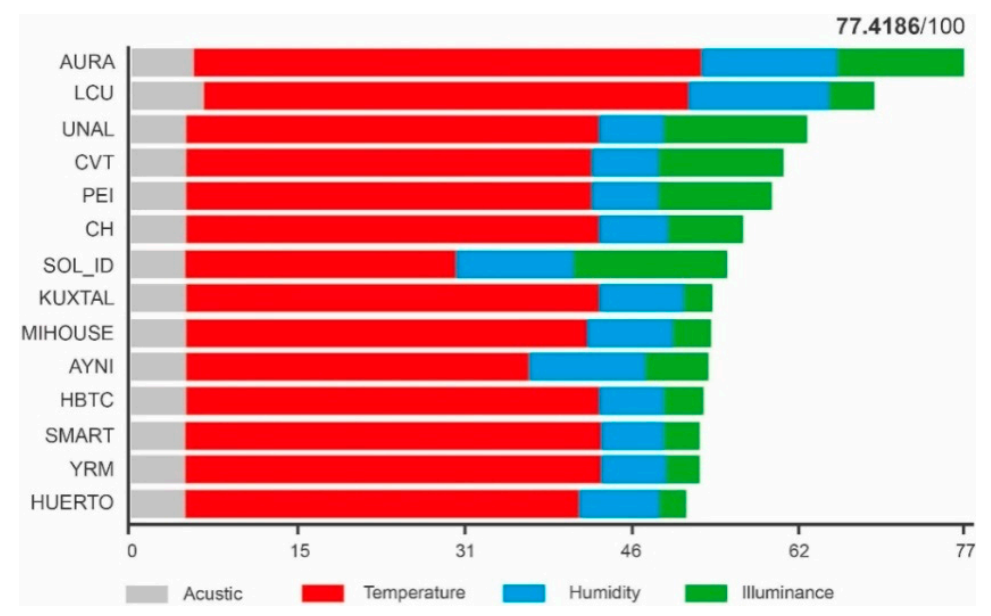

Figure 19. Graph of results by teams of the "Comfort Conditions" test.

To evaluate the comfort conditions in each prototype, the judges installed several Printed Circuit Boards (PCB) in different rooms of each prototype (Figure 20). Those PCB contained the components to obtain the temperature, relative humidity, and lighting data.

Each prototype that participated in the competition was monitored uninterruptedly for 10 days [44,45], 2 sensors were placed in each of them from which temperature data were obtained, 1 sensor where data was collected exclusively on relative humidity, and 1 sensor that provided the levels of natural lighting inside the house.

These sensors were placed on the same criteria in all homes: the sensor for the measurement of natural lighting must be located more than $2 \mathrm{~m}$ from any window, two combined sensors (temperature + humidity) were placed in the living room and a bedroom; and finally, a sensor in the kitchen is responsible for measuring relative humidity in this area of the housing.

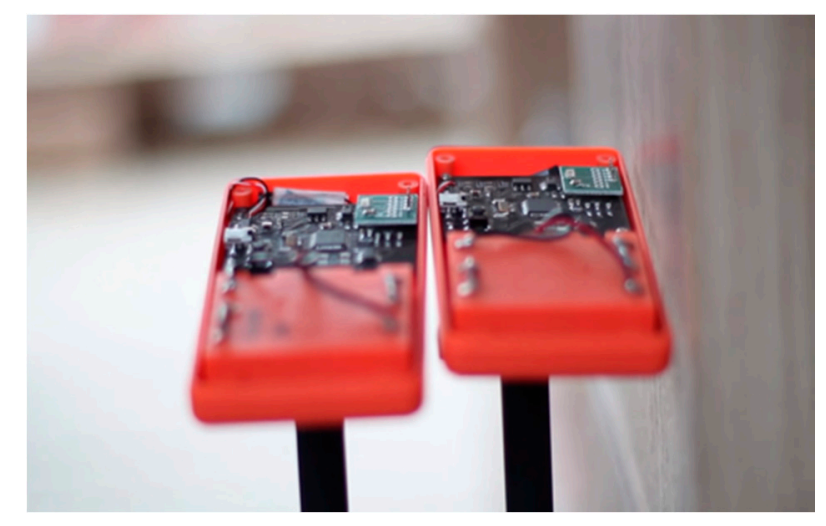

Figure 20. Sensors for monitoring housing.

Focusing on the AURA 1.0 prototype, Figure 21 show the location of this PCB: 


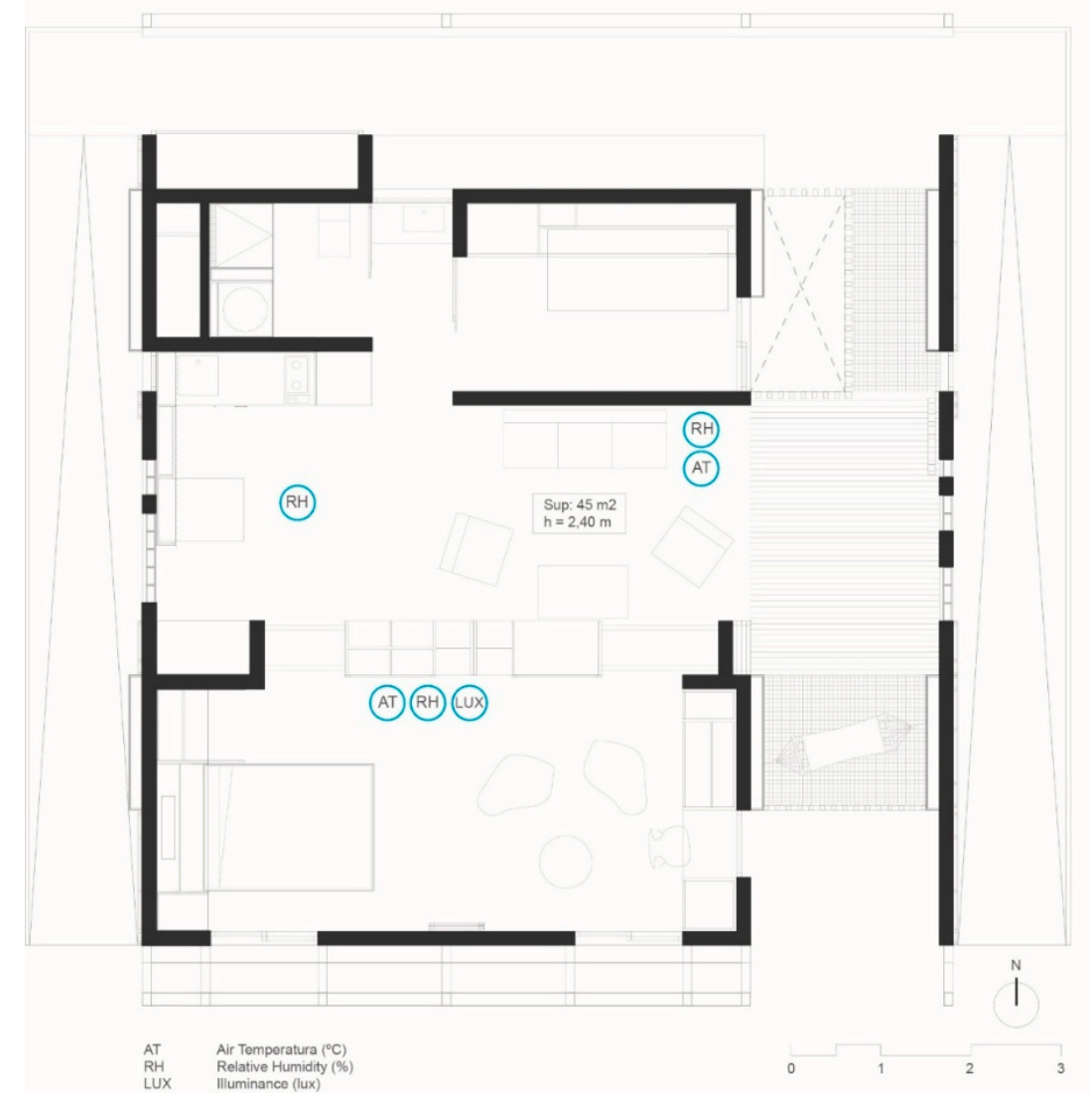

Figure 21. Prototype plant and measurement points.

\subsection{Hygrothermal Data}

The hygrothermal data extracted from the monitoring of the prototype (Figure 22) show us that in relation to relative humidity, the results were very good, with the graph being below $60 \%$ most of the time.

The temperature graph shows an average line of $25^{\circ} \mathrm{C}$, except for peaks during the hottest hours of the day.

It should be noted that temperature and relative humidity measurements were not taken $24 \mathrm{~h}$ a day, but alternated with public opening hours, so that the public did not have a negative impact on the measurements (Table 6).

From these data we can confirm that, in a large percentage of the scoring hours, the prototype was in the maximum score range, and that practically $100 \%$ of the time it was obtaining at least a reduced score. In other words, the percentage of the time when the prototype was getting no points was practically negligible.

In this sense, the greatest achievement of this model is to maintain a relative air humidity in a range suitable for health. This takes on special relevance in a climate like that of Santiago de Cali, where high humidity is one of its characteristic parameters. This prototype managed to keep the humidity below $65 \%$ during $91 \%$ of the time, and it never went up from $70 \%$, so living in the AURA house means avoiding respiratory diseases related to the presence of mold, which is sometimes a consequence of the high environmental humidity. 


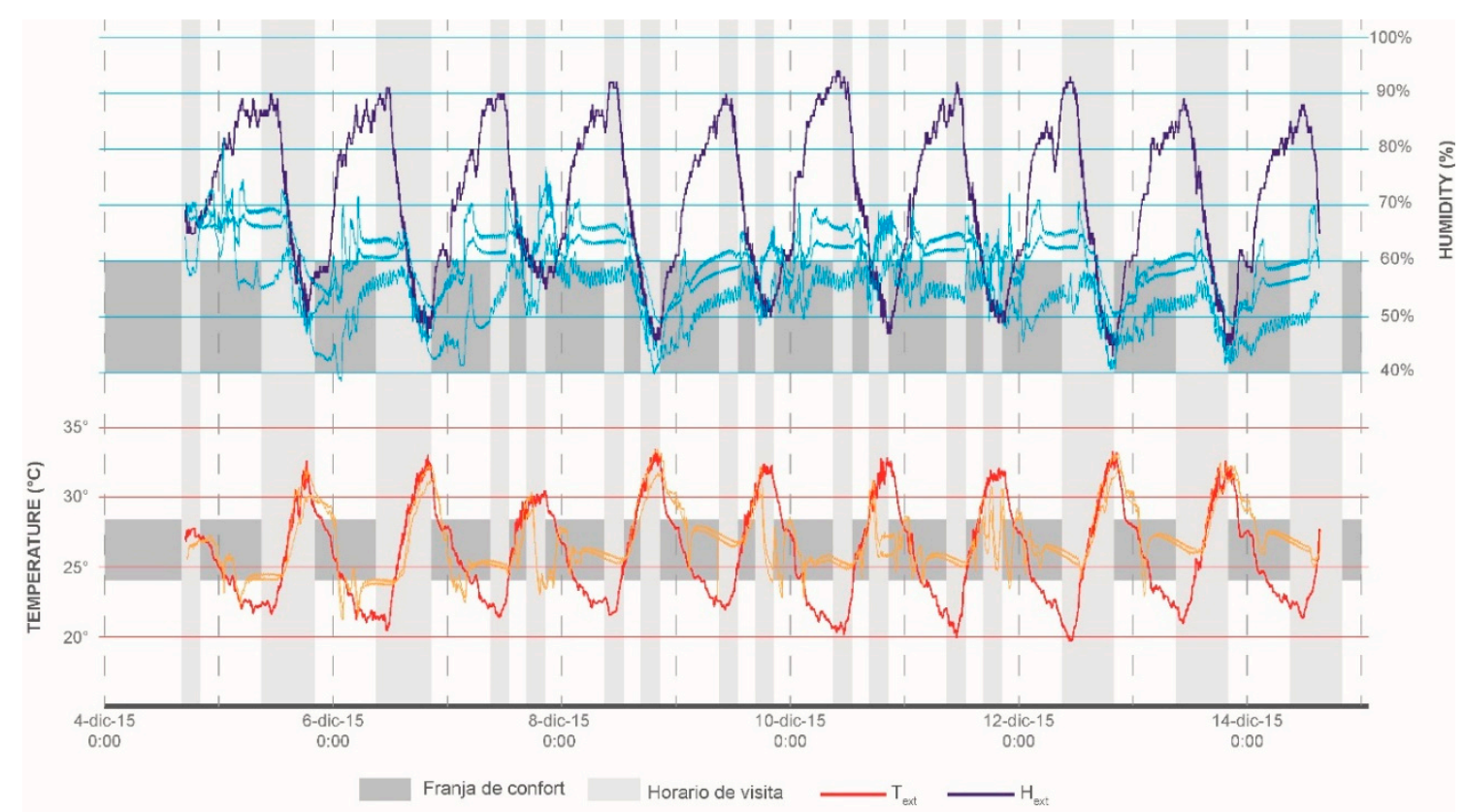

Figure 22. Graph of hygrothermal behavior.

Table 6. Percentage of Hours (in scoring hours) in Comfort Range.

\begin{tabular}{|c|c|c|c|c|}
\hline & & TEMP. & & HUM. REL. \\
\hline MAX. SCORE & Comfort range $>24-<28$ & $68 \%$ & Comfort range $<60 \%$. & $42 \%$ \\
\hline \multirow{2}{*}{ LOW SCORE } & Comfort range $\pm 1^{\circ} \mathrm{C}$ & $14 \%$ & Comfort range $<65 \%->60$ & $49 \%$ \\
\hline & Comfort range $\pm 2{ }^{\circ} \mathrm{C}$ & $11 \%$ & Comfort range $<70 \%->65$ & $9 \%$ \\
\hline NO SCORING & Out of confort range & $7 \%$ & Out of confort range & $0 \%$ \\
\hline
\end{tabular}

\subsection{Lighting Data}

The objective was to achieve lighting values above $4 \%$ of the Natural Lighting Factor or, at least, that their value should never be less than $2.5 \%$ of the latter (Figure 23). Thus, analyzing the behavior of Figure 23, we confirm that the line of interior lighting is above the $2.5 \%$ most of the time, also exceeding the $4 \%$ line by a large percentage, so it is considered that, in this sense, the prototype behaved optimally in relation to this section (Table 7).

These values, which refer to natural lighting, have a positive influence on the well-being of the individual, as well as positively influencing the cognitive function of the brain and helping to strengthen its immune system, thus improving the quality of life of the people living in this dwelling (Table 8).

Table 7. Percentage of Hours (in scoring hours) in Lighting Range.

\begin{tabular}{ccc}
\hline \multirow{2}{*}{ MAXIMUM SCORE } & ILLUM. \\
\hline \multirow{2}{*}{ LOW SCORE } & Daylight Factor $>4 \%$ & $52 \%$ \\
\cline { 2 - 3 } & Daylight Factor $>3 \%$ & $76 \%$ \\
\hline NO SCORING & Out of comfort range & $91 \%$ \\
\hline
\end{tabular}




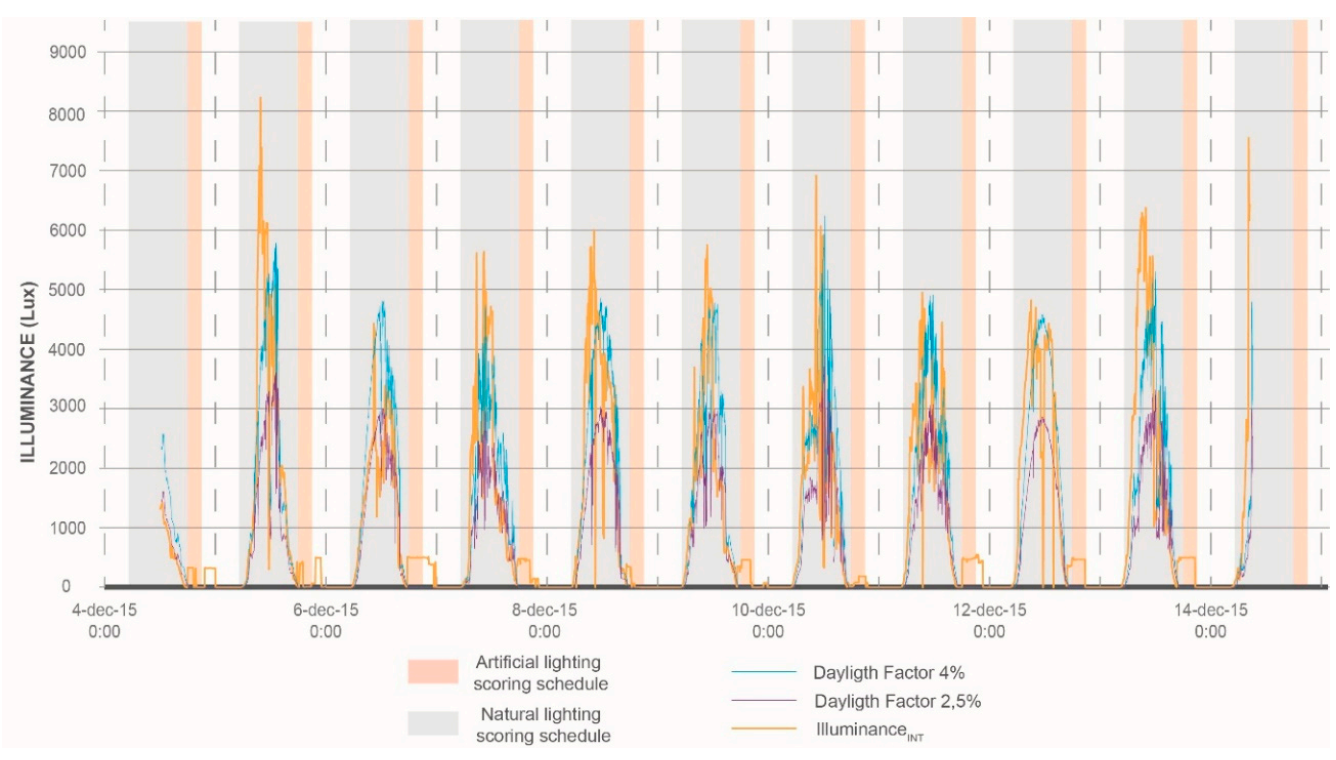

Figure 23. Graph of lighting behavior.

Table 8. Nomenclature table with units.

\begin{tabular}{cc}
\hline Variable & Units \\
\hline Temperature & ${ }^{\circ} \mathrm{C}$ \\
\hline Humidity & $\%$ \\
\hline Illuminance & $\mathrm{Lux}$ \\
\hline Daylight Factor & $\%$ \\
\hline
\end{tabular}

\section{Discussion and Conclusions}

Taking into consideration this analysis, the AURA proposal for sustainable social housing for a tropical climate, presented by the team from the University of Seville at the first Latin American edition of the Solar Decathlon, held in Santiago de Cali (Colombia), proved its high performance in terms of all three analyzed comfort parameters which contribute to improving the quality of life, and therefore, the health of the inhabitants: temperature, relative humidity, and lighting.

The proposal achieved an adequate balance in the implementation and combination of active and passive conditioning strategies, showing that in order to guarantee adequate conditions in social housing, it is necessary to contemplate active conditioning systems. This combination of systems, by combating the adverse climatic conditions typical of tropical climates characterized by a combination of high temperature and relative humidity, appears to be a basic tool for the inhabited spaces to avoid health problems, especially among the most vulnerable population.

It is in the poorest classes of society (population with fewer resources, inhabitants of the so-called "social housing") where the most cases of people suffering from the deficient comfort conditions of their domestic habitat are registered. These deficiencies are due to the lack of equipment to air-condition the spaces and the difficulty these people have to pay for the necessary energy expenditure, and therefore, to produce energy.

It is precisely in this area that passive environmental techniques and energy self-sufficiency become critical: on the one hand, passive conditioning strategies will make an impact in less time than using air-conditioning systems, which will make it possible to obtain more energy-efficient living spaces with optimum bioclimatic design during a large percentage of the hours of the day; on the other hand, when the use of this technology becomes necessary, energy self-sufficiency will allow people with fewer resources to maintain their homes in optimal ranges for their health and comfort, without this 
having repercussions on their socio-economic situation. Furthermore, in this Latin American context, in which there are high rates of energy poverty in most of these countries, all the above explained is especially appropriate from the point of view of economic sustainability, in addition to seeking optimal levels of comfort to the user, which will ultimately affect their health conditions.

In conclusion, as far as sustainable social architecture is concerned, the AURA 1.0 prototype constitutes an adapted and tested sample, with excellent results in a tropical climate, which strategies are perfectly viable and transferable to the society of the Colombian region where it is located. Although the concept of comfort is very broad and its impact on people's health depends on various factors, this project has achieved certain improvements in conditions related to both hygrometric and lighting conditions in domestic spaces.

Although this project is developed for a tropical climate and the conditioning strategies are specific to that climate, the sociological strategies used can be applied to other climatic zones. Therefore, we must understand that social housing needs to be adapted to the socio-economic context of the place, and architects must think about an economic sustainability of housing without reducing the user's comfort and health levels.

Author Contributions: Conceptualization, Á.L.-E., R.H.-L., Á.L.L.-R. and M.T.-G.; Formal analysis, Á.L.-E., R.H.-L., Á.L.L.-R. and M.T.-G.; Investigation, Á.L.-E., R.H.-L., Á.L.L.-R. and M.T.-G.; Methodology, Á.L.-E., R.H.-L., Á.L.L.-R. and M.T.-G.; Writing—original draft, Á.L.-E., R.H.-L., Á.L.L.-R. and M.T.-G.; Writing-review \& editing, Á.L.-E., R.H.-L., Á.L.L.-R. and M.T.-G. All authors have read and agreed to the published version of the manuscript.

Funding: This research received no external funding.

Acknowledgments: The Authors would like to thank Aura Team (Universidad de Sevilla, Spain) who participated in the 2015 edition of the Solar Decathlon Latin America and Caribbean, held in Santiago de Cali (Colombia), for all the data provided for this article.

Conflicts of Interest: The authors declare no conflict of interest.

\section{References}

1. Solar Decathlon 2017 Preview. Available online: http://search.proquest.com/docview/1934411044/ (accessed on 20 April 2020).

2. Herrera-Limones, R.; Rey-Pérez, J.; Hernández-Valencia, M.; Roa-Fernández, J. Student Competitions as a Learning Method with a Sustainable Focus in Higher Education: The University of Seville "Aura Projects" in the "Solar Decathlon 2019.". Sustainability 2020, 12, 1634. [CrossRef]

3. Bot, L.; Gossiaux, P.B.; Rauch, C.P.; Tabiou, S. 'Learning by Doing': A Teaching Method for Active Learning in Scientific Graduate Education. Int. J. Phytoremediat. 2005, 30, 105-119. [CrossRef]

4. Fantozzi, F.; Leccese, F.; Salvadori, G.; Spinelli, N.; Moggio, M.; Pedonese, C.; Formicola, L.; Mangiavacchi, E.; Baroni, M.; Vegnuti, S.; et al. Solar Decathlon ME18 Competition as a "learning by Doing" Experience for Students: The Case of the Team HAAB. In IEEE Global Engineering Education Conference, EDUCON; IEEE Computer Society: Washington, DC, USA, 2018; pp. 1865-1869. [CrossRef]

5. Chiuini, M.; Grondzik, W.; King, K.; McGinley, M.; Owens, J. Architect and Engineer Collaboration: The Solar Decathlon as a Pedagogical Opportunity. In AEI 2013: Building Solutions for Architectural Engineering -Proceedings of the 2013 Architectural Engineering National Conference; ASCE: Reston, VA, USA, 2013; pp. 215-224. [CrossRef]

6. Gutierrez, A.; Jimenez-Leube, J;; Magdalena, L. A Distributed Sensor Network for the Control of a Bioclimatic House in Spain. Sensors 2009, 9, 8197-8214. [CrossRef] [PubMed]

7. Checket-Hanks, B. Welcome Back, Solar Heating-Cooling. Air Cond. Heat. Refrig. News 2007, 232, 27-28.

8. Ferrara, M.; Lisciandrello, C.; Messina, A.; Berta, M.; Zhang, Y.; Fabrizio, E. Optimizing the Transition between Design and Operation of ZEBs: Lessons Learnt from the Solar Decathlon China 2018 SCUTxPoliTo Prototype. Energy Build. 2020, 213, 109824. [CrossRef]

9. Bohm, M. Energy Technology and Lifestyle: A Case Study of the University at Buffalo 2015 Solar Decathlon Home. Renew. Energy 2018, 123, 92-103. [CrossRef] 
10. Battista, G.; Carnielo, E.; Evangelisti, L.; Frascarolo, M.; Vollaro, R. Energy Performance and Thermal Comfort of a High Efficiency House: RhOME for DenCity, Winner of Solar Decathlon Europe 2014. Sustainability 2015, 7, 9681-9695. [CrossRef]

11. Peng, C.; Huang, L.; Liu, J.; Huang, Y. Energy Performance Evaluation of a Marketable Net-Zero-Energy House: Solark I at Solar Decathlon China 2013. Renew. Energy 2015, 81, 136-149. [CrossRef]

12. Terrados, F.J.; Moreno, D. "Patio" and "Botijo": Energetic Strategies' Architectural Integration in "Patio 2.12" Prototype. Energy Build. 2014, 83, 70-88. [CrossRef]

13. Soriano, B.S.; Gimeno, P.V.; Segura, A.D.; De La Maza, R.M. Assembling Sustainable Ideas: The Construction Process of the Proposal SMLsystem at the Solar Decathlon Europe 2012. Energy Build. 2014, 83, 186-194. [CrossRef]

14. Ma, Z.; Ren, H.; Lin, W. A Review of Heating, Ventilation and Air Conditioning Technologies and Innovations Used in Solar-Powered Net Zero Energy Solar Decathlon Houses. J. Clean. Prod. 2019, 240, 118158. [CrossRef]

15. Pollard, A.; Jones, T.; Sherratt, S.; Sharpe, R.A. Use of Simple Telemetry to Reduce the Health Impacts of Fuel Poverty and Living in Cold Homes. Int. J. Environ. Res. Public Health 2019, 16, 2853. [CrossRef] [PubMed]

16. Oree, V.; Anatah, H.K. Investigating the Feasibility of Positive Energy Residential Buildings in Tropical Climates. Energy Effic. 2017, 10, 383-404. [CrossRef]

17. Herrera-Limones, R.; Millán-Jiménez, A.; López-Escamilla, Á.; Torres-García, M. Health and Habitability in the Solar Decathlon University Competitions: Statistical Quantification and Real Influence on Comfort Conditions. Int. J. Environ. Res. Public Health 2020, 17, 5926. [CrossRef]

18. Boubekri, M. Chapter 5-Psychology of Lighting. In Daylighting, Architecture and Health; Architectural Press: New York, NY, USA, 2008; pp. 87-109. [CrossRef]

19. Lawrence, R. Constancy and Change: Key Issues in Housing and Health Research, 1987-2017. Int. J. Environ. Res. Public Health 2017, 14, 763. [CrossRef]

20. Roulet, C.A.; Bluyssen, P.M.; Müller, B.; De Oliveira Fernandes, E. Design of Healthy, Comfortable, and Energy-Efficient Buildings. In Springer Optimization and Its Applications; Springer International Publishing: Berlin/Heidelberg, Germany, 2012; Volume 56, pp. 83-108. [CrossRef]

21. Ali, A.S.; Zanzinger, Z.; Debose, D.; Stephens, B. Open Source Building Science Sensors (OSBSS): A Low-Cost Arduino-Based Platform for Long-Term Indoor Environmental Data Collection. Build. Environ. 2016, 100, 114-126. [CrossRef]

22. Pitarma, R.; Marques, G.; Ferreira, B.R. Monitoring Indoor Air Quality for Enhanced Occupational Health. J. Med. Syst. 2017, 41, 23. [CrossRef]

23. Dong, B.; Lam, K. A Real-Time Model Predictive Control for Building Heating and Cooling Systems Based on the Occupancy Behavior Pattern Detection and Local Weather Forecasting. Build. Simul. 2014, 7, 89-106. [CrossRef]

24. Naicker, N.; Teare, J.; Balakrishna, Y.; Wright, C.; Mathee, A. Indoor Temperatures in Low Cost Housing in Johannesburg, South Africa. Int. J. Environ. Res. Public Health 2017, 14, 1410. [CrossRef]

25. Brambilla, A.; Salvalai, G.; Tonelli, C.; Imperadori, M. Comfort Analysis Applied to the International Standard "Active House": The Case of RhOME, the Winning Prototype of Solar Decathlon 2014. J. Build. Eng. 2017, 12, 210-218. [CrossRef]

26. Peng, C.; Huang, L.; Liu, J.; Huang, Y. Design and Practical Application of an Innovative Net-Zero Energy House with Integrated Photovoltaics: A Case Study from Solar Decathlon China 2013. Archit. Sci. Rev. 2015, 58, 144-161. [CrossRef]

27. Belpoliti, V.; Calzolari, M.; Davoli, P.; Altan, H.; Nassif, R. Design Optimization to Enhance Passive Energy Strategies. The KNOW HOWse Project for Solar Decathlon Middle East 2018. Procedia Manuf. 2020, 44, 302-309. [CrossRef]

28. Tiele, A.; Esfahani, S.; Covington, J. Design and Development of a Low-Cost, Portable Monitoring Device for Indoor Environment Quality. J. Sensors 2018, 2018. [CrossRef]

29. Spencer, B.; Al-Obeidat, F.; Alfandi, O. Accurately Forecasting Temperatures in Smart Buildings Using Fewer Sensors. Pers. Ubiquitous Comput. 2019, 23, 921-929. [CrossRef]

30. Cornaro, C.; Rossi, S.; Cordiner, S.; Mulone, V.; Ramazzotti, L.; Rinaldi, Z. Energy Performance Analysis of STILE House at the Solar Decathlon 2015: Lessons Learned. J. Build. Eng. 2017, 13, 11-27. [CrossRef] 
31. Stanham, Y.; McCarthy, T.J.; Stappenbelt, B. Experimental Analysis of a Water Column and Structure Heave Velocity Relationship for a Floating Oscillating Water Column Wave Energy Device. Aust. J. Mech. Eng. 2018, 16, 230-237. [CrossRef]

32. Jin, Y.; Li, J.; Wu, W. I-Yard 2.0: Integration of Sustainability into a Net-Zero Energy House. Appl. Sci. 2020, 10, 3541. [CrossRef]

33. Herrera-Limones, R.; León-Rodríguez, Á.; López-Escamilla, Á. Solar Decathlon Latin America and Caribbean: Comfort and the Balance between Passive and Active Design. Sustainability 2019, 11, 3498. [CrossRef]

34. Solar Decathlon LatinAmerica\&Caribbean 2015. RULES Final Version. Available online: https: //solardecathlonlac.com/competencia/reglas/ (accessed on 10 December 2015).

35. Herrera, R.; Pineda, P.; Roa, J.; Cordero, S.; López-Escamilla, Á. Project AURA: Sustainable Social Housing. In Sustainable Development and Renovation in Architecture, Urbanism and Engineering; Springer International Publishing: Berlin/Heidelberg, Germany, 2017; pp. 277-287. [CrossRef]

36. Herrera-Limones, R. La Urdimbre Sostenible Como Táctica Para Un Hacer Arquitectónico: De La "Arquitectura de Países Cálidos" Hasta Los Nuevos Escenarios y Modos de Vida Emergentes, a Través de La Dimensión Dialógica. Ph.D Thesis, Universidad de Sevilla, Sevilla, Spain, 2013.

37. Luna-Tintos, J.F.; Cobreros, C.; Herrera-Limones, R.; López-Escamilla, Á. “Methodology Comparative Analysis" in the Solar Decathlon Competition: A Proposed Housing Model Based on a Prefabricated Structural System. Sustainability 2020, 12, 1882. [CrossRef]

38. Luna-Tintos, J.; Cobreros, C.; López-Escamilla, Á.; Herrera-Limones, R.; Torres-García, M. Methodology to Evaluate the Embodied Primary Energy and CO2 Production at Each Stage of the Life Cycle of Prefabricated Structural Systems: The Case of the Solar Decathlon Competition. Energies 2020, 13, 4311. [CrossRef]

39. Wadel, G.; Avellaneda, J.; Cuchí, A. La Sostenibilidad En La Arquitectura Industrializada: Cerrando El Ciclo de Los Materiales. Inf. Constr. 2010, 62, 37-51. [CrossRef]

40. Montes, J.; Camps, I.P.; Fúster, A. Industrialización En La Vivienda Social de Madrid. Inf. Constr. 2011, 63, 5-19. [CrossRef]

41. Li, Z. A New Life Cycle Impact Assessment Approach for Buildings. Build. Environ. 2006, 41, 1414-1422. [CrossRef]

42. Crawford, R.H.; Cadorel, X. A Framework for Assessing the Environmental Benefits of Mass Timber Construction. Procedia Eng. 2017, 196, 838-846. [CrossRef]

43. Yu, Z.; Gou, Z.; Qian, F.; Fu, J.; Tao, Y. Towards an Optimized Zero Energy Solar House: A Critical Analysis of Passive and Active Design Strategies Used in Solar Decathlon Europe in Madrid. J. Clean. Prod. 2019, 236, 117646. [CrossRef]

44. Wassmer, M.R.; Warner, C.L. Building-Energy Simulation and Monitoring Research Activities for Solar Decathlon Houses. In Proceedings of the Conference Record of the Thirty-first IEEE Photovoltaic Specialists Conference, Lake Buena Vista, FL, USA, 3-7 January; 2005; pp. 1714-1717. [CrossRef]

45. Zamora-Martínez, F.; Romeu, P.; Botella-Rocamora, P.; Pardo, J. On-Line Learning of Indoor Temperature Forecasting Models towards Energy Efficiency. Energy Build. 2014, 83, 162-172. [CrossRef]

Publisher's Note: MDPI stays neutral with regard to jurisdictional claims in published maps and institutional affiliations.

(C) 2020 by the authors. Licensee MDPI, Basel, Switzerland. This article is an open access article distributed under the terms and conditions of the Creative Commons Attribution (CC BY) license (http://creativecommons.org/licenses/by/4.0/). 